\title{
7 años de dA webCenter
}

Keywords: Derecho Animal, Derecho del Bienestar Animal, seres sintientes, protección animal, políticas públicas

DA webCenter es una página web innovadora. ¿Porque trata de animales? No, en absoluto. Páginas web que tratan de animales las hay a centenares.

Es la primera web de España que, desde hace siete años, abordó el Derecho Animal y el Bienestar Animal desde el punto de vista del análisis científico y riguroso del Derecho y los avances científicos en materia de animales y lo hizo -y lo sigue haciendo-, desde una perspectiva puramente académico-jurídica. Por tal razón su publicación y permanencia tiene razón de ser.

Lo que pretendemos, es acercar el Derecho Animal a todas aquellas personas que se quieran aproximar a él desde una perspectiva rigurosa, seria y, a la vez, sencilla, clara y asequible. DA webCenter no ha querido ser un medio de expresión del activismo animalista, movimiento que, ya ha tenido y sigue teniendo repercusión a través de otros medios.

¿Por qué razón podemos encontrar webs especializadas en Derecho del Medio Ambiente y ninguna web especializada en Derecho Animal?, porque las otras son disciplinas (o ramas) respetadas y reconocidas en el ámbito jurídico, mientras que el Derecho Animal, por su carácter novedoso, aún no es estudiado de la forma generalizada que requeriría. Nuestra contribución, en este ámbito es importante y ya está reconocida. La web está referenciada en las webs oficiales de la UAB, de la Facultad de Derecho de la UAB, del Departamento de Derecho Público y Ciencias HistóricoJurídicas de la UAB, en la web de la State University of Michigan editada por el Prof. David Favre, en muchas webs de Latinoamérica. La web es el futuro de la información jurídica en este nuevo ámbito del Derecho que es el Derecho Animal del que ya se están haciendo eco los los profesionales y la sociedad.

DA webCenter pretende paliar este déficit de información, existente hasta el momento, pero, al mismo tiempo, no quiere limitarse a ser un portal académico, sino que también busca la repercusión en el gran público, a través de la publicación de noticias, de sentencias y de eventos que pueden interesar tanto a juristas como a no juristas. Prueba de ello son las visitas que ha recibido la web en el último año -siempre crecientes- y los muchos "me gusta” que tiene la página en Facebook, recibidas en un corto espacio de tiempo desde que la web se introdujo en las redes sociales.

Lo que nos distingue es:

-la publicación de materiales de autor, sometidos a una revisión por pares. No publicamos material cortado o copiado de otras webs.

-La actualización permanente de los datos. Somos la única web jurídica en tema de animales que mantiene actualizada la legislación en esta materia. El resto de webs suele tener una sección de información jurídica que, aparte de ser incompleta, no se actualiza, por lo que no brinda una información fehaciente, ni al público, ni al ciudadano medio. 
-Hemos creado la primera y única base de datos jurídica en tema de Animales y Derecho. Somos un referente. Lo confirman los muchísimos ciudadanos, estudiantes, profesionales del derecho y la veterinaria que consultan la web, pues, lo dicen: siempre se encuentra el dato que se busca, de forma sencilla, y siempre está al día.

-La web está contribuyendo a crear conciencia ciudadana y respeto por los animales. No usamos nunca el sensacionalismo, ni la divulgación de imágenes violentas. Nuestro fuerte es la persuasión a través de la claridad, del dato contrastado, de la argumentación serena. Lo que nos inspira -nuestra misión-, es trabajar más y mejor por los principales destinatarios de nuestros esfuerzos: los animales.

-La posición de la web en España y fuera de España se afirma de modo exponencial, cada día.

-La web nació asesorada por un Consejo Editorial, formado por personalidades reconocidas mundialmente en el campo de esta especialidad. Todos ellos publican artículos de referencia en nuestro espacio. El valor que tiene esta contribución es que, desde el principio, hemos querido ser una web sólida, reconocida y respetada. Y lo somos.

-La DA web Center es el mejor instrumento de formación e información para el Master in Animal Law and Society, presencial y online. Hasta ahora somos el único Master en Europa en este ámbito y el primero que se creó en el mundo. El Master de la Lewis and Clark University se creó el año 2012.

Siempre reconoceremos que la Fundación Affinity hizo una apuesta por esta web, cuando no existía -como existe ahora-, un equipo entusiasta de voluntarios capaz de hacerla realidad. Una apuesta hecha cuando de Derecho Animal no se hablaba. Esta es una gran aportación de la Fundación Affinity y de la UAB: haber creído posible y haber apoyado esta iniciativa.

Si se nos pregunta qué metas tenemos y en qué podríamos mejorar, me ceñiré a tres aspectos solamente, a título ejemplificativo:

-En primer lugar, queremos aumentar nuestro liderazgo. Queremos ser una web que siga prestando un servicio a los animales y que esté cerca de quien requiera nuestra "expertise”. Es claro que, para ello, necesitamos tener un equipo permanente, o, al menos, continuado.

-En segundo lugar, queremos fortalecer un vínculo entre los profesionales, expertos en Derecho Animal que han estudiado el Master en Derecho Animal y Sociedad, a través de la web con otros profesionales que puedan hacer una verdadera networking y beneficiar, como una red fuerte, el trabajo por y para los animales, desde un ámbito profesional. Esta es la tendencia que se afirma en toda Europa y, desde luego, en USA, Canadá y Australia.

-En tercer lugar, queremos crecer en dimensión y en influencia. Nuestro lema es "saber más para trabajar mejor por los animales”.

En estos años hemos visto cambiar la sensibilidad ciudadana hacia los animales como lo pone de manifiesto el aumento de denuncias por maltrato animal -tal como recogen nuestros Boletines de Noticias de los Tribunales y Noticias Legislativas-, han aparecido nuevas iniciativas en favor de los animales, sobre todo desde los Colegios de Abogados donde se han creado nuevas Comisiones de Derecho Animal, se han multiplicado los esfuerzos por mejorar la legislación autonómica y local, se han promovido políticas públicas en defensa de los intereses de los animales, hemos visto nacer un 
nuevo diálogo entre el Derecho y la Ciencia del Bienestar Animal, que nosotros promovimos desde nuestro inicio. Todo ello está repercutiendo en una nueva dimensión de la ciencia del Derecho, que es la integración de los animales como seres sintientes dentro del sistema jurídico vigente.

Personalmente, no soy amiga de "vender humo". En su momento no hicimos una presentación de la web, porque no pareció oportuno. Sin embargo, pienso que ahora, tras siete años de trabajo, es el momento de presentarnos a los medios jurídicos y ciudadanos. 